\title{
Role of glycogen metabolism in pancreatic islet beta cell function
}

\author{
Willy J. Malaisse ${ }^{1}$
}

Received: 20 July 2016 / Accepted: 1 August 2016 / Published online: 27 August 2016

(C) Springer-Verlag Berlin Heidelberg 2016

Keywords Glucotoxicity · Glycogen · Insulin secretion · Islet beta cell

\author{
Abbreviations \\ Gys $1^{\mathrm{KO}} \quad$ Glycogen synthase 1 knockout mouse model \\ PTG Protein targeting to glycogen \\ $\mathrm{PTG}^{\mathrm{OE}}$ Protein targeting to glycogen over-expressing \\ mouse model \\ RIP Rat insulin II promoter
}

To the Editor: In light of the recent publication in Diabetologia by Mir-Coll et al, entitled 'Genetic models rule out a major role of beta cell glycogen in the control of glucose homeostasis' [1], this letter aims to remind readers of evidence supporting a major role for beta cell glycogen accumulation in perturbation of glucose-stimulated insulin secretion observed in non-insulin dependent diabetes [2].

A role for glycogenolysis in insulin secretion was first proposed in 1967, when theophylline was found to stimulate insulin secretion from pieces of pancreatic tissue obtained from severely hyperglycaemic rats (glucose infused for 8 $10 \mathrm{~h}$ ), even when incubated in the absence of hexose. This was not observed in pancreatic tissue from normoglycaemic rats incubated without glucose [3]. Importantly, glycogen was detected histologically in the islets of hyperglycaemic rats. In the pieces of pancreas removed from hyperglycaemic rats and

Willy J. Malaisse

malaisse@ulb.ac.be

1 Department of Biochemistry, Université Libre de Bruxelles, 808 Route de Lennik, B-1070 Brussels, Belgium incubated in the absence of glucose, theophylline-induced insulin release was unaffected by mannoheptulose, which inhibits glucose phosphorylation, but was suppressed by 2deoxyglucose, which inhibits the isomerisation of glucose-6phosphate to fructose-6-phosphate and, thus, decreases glycolysis.

Subsequently, it was documented that rat islets preincubated with $83.3 \mathrm{mmol} / \mathrm{l}$ glucose for $20 \mathrm{~h}$ contained large amounts of glycogen ( $76 \pm 12 \mathrm{pmol}$ glucose residue/islet), whilst no significant glycogen was detected in islets prior to glucose preincubation. In glucose-preincubated islets, theophylline stimulated insulin release, accelerated glycogenolysis rate and augmented lactate output. Theophylline also increased ${ }^{14} \mathrm{CO}_{2}$ output from islets preincubated in the presence of $\mathrm{D}-\left[\mathrm{U}_{-}{ }^{14} \mathrm{C}\right]$ glucose and incubated in the absence of glucose [4]. Moreover, both in the absence and presence of theophylline, the decrease in islet glycogen content during a final 30 min incubation closely matched the amount of carbon appearing as either lactate or ${ }^{14} \mathrm{CO}_{2}[4]$.

More importantly from the perspective of diabetes, beta cell glycogen accumulation accounts for two typical features of beta cell glucotoxicity in non-insulin dependent diabetes, i.e. a paradoxical early inhibition of insulin output in response to i.v. glucose administration and altered anomeric specificity of the beta cell secretory response to glucose [2].

A paradoxical early decrease in insulinaemia after i.v. glucose administration was first observed in non-insulin dependent diabetic individuals deprived of glucose-lowering therapy for 3 days prior to glucose administration [5]. When a second test was performed after $24 \mathrm{~h}$ of i.v. insulin infusion and normalisation of blood glucose levels, the early secretory response to glucose was clearly improved, with mean positive increments in insulinaemia at 1,3 and 5 min [5]. Paradoxical insulin secretory responses to changes in extracellular glucose concentration also occur in perfused pancreases obtained from 
rats infused for $48 \mathrm{~h}$ with a hypertonic solution of glucose, in which average islet glycogen content was $41.9 \pm 10.8 \mathrm{pmol}$ glucose residue/islet, compared with $1.2 \pm 0.9 \mathrm{pmol} /$ islet in controls [6].

Similarly, perturbation of the anomeric specificity of the beta cell secretory response to glucose was first documented in non-insulin-dependent diabetic individuals with moderate hyperglycaemia [7], with comparable findings in rats given streptozotocin during the neonatal period [8], diabetic biobreeding (BB) rats [9] and duct-ligated rabbits [10]. Even in normal rats rendered mildly hyperglycaemic by oral administration of diazoxide for $48 \mathrm{~h}$, the $\alpha: \beta$ ratio in insulin output was $50 \%$ of controls [11].

Accelerated glycogenolysis is the major determinant of paradoxical early changes in insulin secretion in response to reduced extracellular glucose concentration $[12,13]$. The perturbation of the anomeric specificity of the insulin secretory response to glucose is also attributable to interference of glycogenolysis with glycolysis [12]; $\alpha$-D-glucose is more potent than $\beta$-D-glucose in inhibiting phosphorylase a, or inactivating phosphorylase by phosphorylase phosphatase [14].

In their investigations, Mir-Coll and colleagues used two genetic mice models [1]; the first investigations concerned mice with pancreas-specific knock out of glycogen synthase 1 (Gys $1^{\mathrm{KO}}$ mice). The reduction of Gys 1 mRNA and protein was duly documented in isolated islets. Body weight, blood glucose and insulin levels (after overnight fast and during IPGTT), islet insulin content and insulin release by freshly isolated islets incubated with 2.8 or $16.7 \mathrm{mmol} / \mathrm{l}$ glucose for $90 \mathrm{~min}$ were all similar in $G y s^{\mathrm{KO}}$ and control animals. Relative expression of functionally relevant genes (Glut2, Gck, Ins1/Ins2) was also similar between Gys $1^{\mathrm{KO}}$ and controls. Although islet glycogen content was not measured, it was concluded that glycogen metabolism is not required for adequate beta cell function [1]. This view agrees with prior findings, since the islets of healthy rats contain virtually no glycogen [6]. Unfortunately, advantage was not taken of this model to determine if Gys $1^{\mathrm{KO}}$ mice are protected against beta cell glucotoxicity.

The second set of experiments used a transgenic model $\left(\mathrm{PTG}^{\mathrm{OE}}\right.$ ) overexpressing protein targeting to glycogen (PTG) in beta cells. This scaffolding protein acts as a hub between glycogen synthase, protein phosphatase 1 and glycogen, in promoting glycogen synthesis. To drive the expression of PTG in beta cells, mice conditionally expressing Ppp $1 r 3 c$ on the action of Cre recombinase were crossed with rat insulin II promoter (RIP)-cre mice. When compared to control RIPcre mice, isolated pancreatic islets of $\mathrm{PTG}^{\mathrm{OE}}$ displayed a 30fold increase in Ppp $1 r 3 \mathrm{c}$ mRNA and 3.5-fold higher glycogen levels in islets freshly isolated from fed mice. In $\mathrm{PTG}^{\mathrm{OE}}$ and control mice fasted overnight, glycogen levels in freshly isolated islets were negligible. The regulation of glycogen accumulation in $\mathrm{PTG}^{\mathrm{OE}}$ beta cells was documented by comparison of the glycogen content in islets obtained from fed rats and cultured for $24 \mathrm{~h}$ at either low vs high glucose concentration. Compared to controls, $\mathrm{PTG}^{\mathrm{OE}}$ mice displayed no difference in beta cell mass or size, islet size distribution, alpha cell mass, body weight, blood glucose pattern during IPGTT, islet insulin content, or in insulin secretion by freshly isolated islets incubated for $90 \mathrm{~min}$ with 2.8 or $16.7 \mathrm{mmol} / \mathrm{l}$ glucose, or $16.7 \mathrm{mmol} / 1$ glucose combined with $10 \mu \mathrm{mol} / 1$ forskolin. Relative mRNA expression of genes essential for sustaining beta cell function was also similar in $\mathrm{PTG}^{\mathrm{OE}}$ and controls [1].

Conceptually, the experiments conducted in $\mathrm{PTG}^{\mathrm{OE}}$ mice are relevant to the possible consequence of excessive beta cell glycogen accumulation on functional behaviour of these cells. However, the following concerns should not be ignored; first, blood insulin measurements during the IPGTT do not contribute to knowledge in this research area since the test was conducted following overnight fast, when islet glycogen content is negligible in $\mathrm{PTG}^{\mathrm{OE}}$ and control mice. Second, in both control and $\mathrm{PTG}^{\mathrm{OE}}$ mice no significant change in insulinaemia was observed during the IPGTT at zero vs $30 \mathrm{~min}$ [1], whereas, under identical experimental conditions in normal mice, insulinaemia peaks at $30 \mathrm{~min}$ after i.p. administration of $2 \mathrm{~g}$ glucose/kg body weight [15]. In respect of this, Mir-Coll et al refer to a prior publication in which, at least in hepatocytes, PTG modifies glycogen phosphorylase phosphorylation and activity [1]. Thus, perhaps one could question the suitability of $\mathrm{PTG}^{\mathrm{OE}}$ mice to assess the role of beta cell glycogenolysis in glucose homeostasis? Third, in investigations into islet insulin release, islets were first incubated for $30 \mathrm{~min}$ at low glucose levels, but beta cell glycogen content levels during this preincubation were not reported. Last, the most relevant experiment concerning the possible role of beta cell glycogen in the secretory response to glucose, the effect of forskolin on insulin release from islets incubated with glucose at low concentrations, was not performed. Despite this, Mir-Coll et al speculate that, after an overnight fast, glycogenolysis in the beta cells of $\mathrm{PTG}^{\mathrm{OE}}$ mice may stimulate insulin release and thus increase fasting insulin levels. Hence, a role for beta cell glycogen in the control of glucose homeostasis is not totally ruled out!

In conclusion, it remains correct to incriminate glycogen accumulation in pancreatic insulin-producing cells as a key determinant of beta cell glucotoxicity.

Acknowledgements The secretarial help of C. Demesmaeker is acknowledged.

Funding This work received no specific grant from any funding agency in the public, commercial or not-for-profit sectors.

Duality of interest The author declares that there is no duality of interest associated with this manuscript.

Contribution statement WJM was the sole contributor to this paper. 


\section{References}

1. Mir-Coll J, Duran J, Slebe F et al (2016) Genetic models rule out a major role of beta cell glycogen in the control of glucose homeostasis. Diabetologia 59:1012-1020

2. Malaisse WJ (1991) Physiology of insulin secretion and its alteration in diabetes: the concept of glucotoxicity. In: Andreani D, Gueriguian JL, Striker GE (eds) Diabetic complications: epidemiology and pathogenetic mechanisms. Raven Press, New York, pp 3-23

3. Malaisse WJ, Malaisse-Lagae F, Mayhew DA (1967) A possible role for the adenylcyclase system in insulin secretion. J Clin Invest 46:1724-1734

4. Malaisse WJ, Sener A, Koser M, Ravazzola M, Malaisse-Lagae F (1977) The stimulus-secretion coupling of glucose-induced insulin release. Insulin release due to glycogenolysis in glucose-deprived islets. Biochem J 164:447-454

5. Gomis R, Novials A, Coves MJ, Casamitjana R, Malaisse WJ (1989) Suppression by insulin treatment of glucose-induced inhibition of insulin release in non-insulin-dependent diabetics. Diabetes Res Clin Pract 6:191-198

6. Marynissen G, Leclercq-Meyer V, Sener A, Malaisse WJ (1990) Perturbation of pancreatic islet function in glucose-infused rats. Metabolism 39:87-95

7. Rovira A, Garrotte FJ, Valverde I, Malaisse WJ (1987) Anomeric specificity of glucose-induced insulin release in normal and diabetic subjects. Diabetes Res 5:119-124
8. Niki A, Niki H, Niki I, Kunoh Y (1988) Insulin release by glucose anomers in a rat model of non-insulin-dependent diabetes. Diabetologia 31:65-67

9. Leclercq-Meyer V, Marchand J, Malaisse WJ (1987) Alteration of the insulin secretory response to D-glucose anomers in diabetic BB rats. Med Sci Res 15:1535-1536

10. Fichaux F, Marchand J, Yaylali B, Leclercq-Meyer V, Catala J, Malaisse WJ (1991) Altered anomeric specificity of glucoseinduced insulin release in rabbits with duct-ligated pancreas. Int J Pancreatol 8:151-167

11. Leclercq-Meyer V, Marchand J, Malaisse WJ (1991) Attenuated anomeric difference of glucose-induced insulin release in the perfused pancreas of diazoxide-treated rats. Horm Metab Res 23:257261

12. Malaisse WJ, Marynissen G, Sener A (1992) Possible role of glycogen accumulation in B cell glucotoxicity. Metabolism 41:814 819

13. Malaisse WJ, Maggetto C, Leclercq-Meyer V, Sener A (1993) Interference of glycogenolysis with glycolysis in pancreatic islets from glucose-infused rats. J Clin Invest 91:432-436

14. Bollen M, Malaisse-Lagae F, Malaisse W, Stalmans W (1990) The interaction of phosphorylase $a$ with $\mathrm{D}$-glucose displays $\alpha$-stereospecificity. Biochim Biophys Acta 1038:141-145

15. Andrikopoulos S, Blair AR, Deluca N, Fam BC, Proietto J (2008) Evaluating the glucose tolerance test in mic. Am J Physiol Endocrinol Metab 295:E1323-E1332 